\section{Growth of Chrysanthemum with Ground Automobile Tires Used as a Container Soil Amendment}

\author{
Daniel C. Bowman \\ Department of Biochemistry, University of Nevada, Reno, NV 89557
}

\author{
Richard Y. Evans and Linda L. Dodge \\ Department of Environmental Horticulture, University of California, Davis, \\ CA 95616
}

Additional index words. Chrysanthemum $\times$ morifolium, Dendranthema $\times$ grandiflorum, soil physical properties, tissue analysis, zinc

\begin{abstract}
A study was conducted to determine the potential for using ground automobile tires as a container medium amendment. Rooted cuttings of chrysanthemun[Dendranthema $\times$ grandiflorum (Ramat.) Kitamura] were planted in 1.56-liter pots containing 1 sand :2 sawdust (v/v) or media in which coarsely or finely ground particles of rubber substituted for $33 \%, 67 \%$, or $100 \%$ of the sawdust. Amendment with the coarse material decreased total porosity and container capacity and increased air-filled porosity and bulk density relative to the sawdust control. Amending the medium with the fine material did not appreciably alter total porosity, container capacity, or bulk density, but did increase airfilled porosity. Plant height, fresh weight, dry weight, and number of open flowers were reduced significantly in rubber-amended media compared to sawdust controls. Rubber amendment reduced shoot tissue concentrations of $\mathrm{N}, \mathrm{P}, \mathrm{K}, \mathrm{Ca}, \mathrm{Mg}$, and $\mathrm{Cu}$, but increased $\mathrm{Zn}$ as much as 74-fold over control values. There was no accumulation of other heavy metals $(\mathrm{Cd}, \mathrm{Cr}, \mathrm{Ni}, \mathrm{Pb})$ or $\mathrm{Na}$ in the tissue due to rubber amendment. This study demonstrates that ground tires might be used as a component of container media in the production of greenhouse chrysanthemums. However, growth reductions and the potential for Zn toxicity may limit the usefulness of ground tires as a substitute for conventional organic amendments.
\end{abstract}

Horticultural container media may be formulated from a variety of materials, with the goal to optimize physical and nutritional characteristics. University of California-type soil mixes (Matkin and Chandler, 1957) are composed of fine sand and an organic component, such as peatmoss, composted sawdust, or bark. These mixes are used extensively throughout the western United States in greenhouse and nursery production. However, suitable organic amendments are becoming expensive and increasingly difficult to obtain. Thus, there is a need to identify alternative materials that can successfully substitute for the common organic amendments.

Various agricultural and municipal waste materials have been evaluated as organic amendments of container media. One of the most important considerations in formulating a container medium, regardless of the materials used, is the particle size of the individual components. Particle size largely determines

Received for publication 16 Aug. 1993. Accepted for publication 5 Jan. 1994. We thank Mike Wicks and Mike Chambers at U.S. Bureau of Mines for technical support. Mention of a trade name, product, or vendor does not imply endorsement by either the Univ. of Nevada or the Univ. of California, nor criticism of ones not mentioned. The cost of publishing this paper was defrayed in part by the payment of page charges. Under postal regulations, this paper therefore must be hereby marked advertisement solely to indicate this fact. the physical properties (total porosity, airfilled porosity, and container capacity) of the medium. For example, increasing the particle size of the sand in a sand: peat mix decreased total porosity and container capacity, but increased air-filled porosity (Bunt, 1976).

Discarded automobile tires, which are plentiful in most parts of the country, can be ground to a coarse particle size comparable to composted sawdust or bark or a fine particle size similar to that of peatmoss. Such materials might impart physical properties similar to formulate the media.

${ }^{2}$ By volume. those of a typical organic amendment in container media. If the chemical properties of ground tires are not deleterious, using tires in horticultural production could help solve the need for inexpensive organic amendments and the disposal problems associated with discarded tires. However, we found no published information on using ground tires in horticultural substrates. This research was conducted to determine if ground rubber could be used successfully as a component of container media.

\section{Materials and Methods}

A study was conducted in the greenhouse beginning in Feb. 1992. Seven media (Table 1) were formulated from sand, redwood sawdust, and two different particle sizes of ground automobile tires (Rebound, International Soils Systems, Fort Collins, Colo.). Particle size distributions of the coarsely (CT) and finely ground (FT) tire material and the sand and sawdust were determined (Table 1). Plastic pots (15 $\mathrm{cm}$ in diameter, 1.56 liter) were filled with each medium, and then the following chemical amendments were mixed thoroughly into each pot: $5.0 \mathrm{~g}$ dolomite, $2.0 \mathrm{~g}$ single superphosphate $(0 \mathrm{~N}-20 \mathrm{P}-0 \mathrm{~K}), 1.0 \mathrm{~g}$ MicroMax (Sierra Chemical Co., Milpitas, Calif.), $1.0 \mathrm{~g} \mathrm{CaCO}_{3}, 0.5 \mathrm{~g} \mathrm{KNO}_{3}$, and $0.3 \mathrm{~g}$ $\mathrm{K}_{2} \mathrm{~S} \mathrm{O}_{4}$.

Rooted cuttings of 'Bright Golden Anne' chrysanthemum were planted four per pot on 12 Feb. 1992. Plants were grown in a glass greenhouse operated at 24/16C (day/night) under long-day conditions (incandescent light from 10:00 PM to 2:00 AM) until 24 Feb. Plants then were pinched, and short-day conditions (8 h light) were imposed. All plants were pruned to three breaks and sprayed to runoff with $2500 \mathrm{mg}$ butanedioic acid mono(2,2dimethylhydrazide) (B-nine, daminozide)/liter on 8 Mar. Disbudding began 30 Mar., and plants were harvested 22 Apr. Plants were irrigated daily with half-strength Hoagland's solution A (Hoagland and Arnon, 1950) throughout the 10 weeks of the experiment.

Growth measurements (plant height per

Table 1. Sand : redwood sawdust : rubber ratios of the seven media used to grow chrysanthemum and the particle size distribution of the sand, sawdust, coarse tire (CT), and fine tire (FT) material used to

\begin{tabular}{|c|c|c|c|c|c|}
\hline \multirow[b]{2}{*}{ Medium } & \multirow{2}{*}{$\begin{array}{c}\text { Media formulation } \\
\text { (sand : sawdust: rubber) }^{2}\end{array}$} & \multicolumn{4}{|c|}{ Particle size distribution (\% by wt) } \\
\hline & & Sand & Sawdust & CT & FT \\
\hline Control & $3: 6: 0$ & & & & \\
\hline \multicolumn{6}{|l|}{ CT $(\%)$} \\
\hline 22 & $3: 4: 2$ & & & & \\
\hline 44 & $3: 2: 4$ & & & & \\
\hline 66 & $3: 0: 6$ & & & & \\
\hline \multicolumn{6}{|l|}{ FT $(\%)$} \\
\hline 22 & $3: 4: 2$ & & & & \\
\hline 44 & $3: 2: 4$ & & & & \\
\hline 66 & $3: 0: 6$ & & & & \\
\hline \multicolumn{6}{|c|}{ Particle diam $(\mathrm{mm})$} \\
\hline$>2.0$ & & 0 & 35.0 & 98.4 & 0 \\
\hline $1.0-2.0$ & & 0 & 31.4 & 1.1 & 30.2 \\
\hline $0.5-1.0$ & & 0.1 & 21.9 & 0.1 & 34.2 \\
\hline $0.25-0.5$ & & 23.9 & 7.4 & 0.1 & 32.4 \\
\hline $0.1-0.25$ & & 69.7 & 3.5 & 0.2 & 0 \\
\hline$<0.1$ & & 5.3 & 0.8 & 0.1 & 3.2 \\
\hline
\end{tabular}


pot, number of open flowers and flower buds per pot, total fresh and dry weights) and tissue ion concentration $(\mathrm{N}, \mathrm{P}, \mathrm{K}, \mathrm{Ca}, \mathrm{Mg}, \mathrm{Na}, \mathrm{Fe}$, $\mathrm{Mn}, \mathrm{Zn}, \mathrm{Cu}, \mathrm{Mo}, \mathrm{Cd}, \mathrm{Cr}, \mathrm{Ni}, \mathrm{Pb}$ ) were collected. Nitrogen was determined by Kjeldahl digestion (Bowman et al., 1988), and all other ions were analyzed by inductively coupled plasma emission spectrometry. The experiment was conducted as a randomized $2 \times 4$ factorial (rubber particle size $\times$ rate) design with five replications. Physical properties of the seven media were determined on three replicates as described by Bowman et al. (1990). We analyzed data by analysis of variance, separated means by least significant difference, and performed trend analysis using orthogonal polynomials.

\section{Results and Discussion}

Amending the medium with CT significantly reduced total porosity and container capacity, and increased air-filled porosity and bulk density relative to the control medium (Table 2). The low values for container capacity with $44 \%$ CT and 66\% CT suggest that they might be droughty. By contrast, total porosity, container capacity, and bulk density were only slightly affected by FT amendment, but air- filled porosity in the $66 \%$ FT treatment increased $62 \%$ over the control. A similar effect of particle size on medium physical properties has been reported for a peat : vermiculite medium (Milks et al., 1989). Air-filled porosity values for the control and the $22 \%$ and the $44 \%$ FT treatments were below the published minimum aeration requirement of $5 \%$ for chry santhemum (Bunt, 1976).

Compared to controls, cuttings transplanted to media containing ground rubber were slow to establish and initially exhibited stress symptoms characterized by small dark-colored leaves with chlorotic margins, thin brittle stems, and incipient wilting. Although initially stressed plants recovered after several weeks, they remained smaller and less robust than the controls throughout the experiment. Shoots in media amended with ground rubber were as much as $27 \%$ shorter than controls (Table 3 ). Although total number of flowering shoots (flowers plus buds) was not affected by media composition, plants grown in media amended with rubber at the higher rates had fewer open flowers than controls. Plant fresh weight and dry weight decreased linearly $(P<0.01)$ with increasing amendment rate. Reductions in the number of open flowers, fresh weight, and dry weight were significantly greater for plants

Table 2. Physical properties of container media formulated with coarse (CT) or fine tire (FT) material. Values are means of three replicates.

\begin{tabular}{|c|c|c|c|c|}
\hline \multirow[b]{2}{*}{ Medium } & \multirow{2}{*}{$\begin{array}{c}\text { Container } \\
\text { capacity (vol \%) }\end{array}$} & \multicolumn{2}{|c|}{ Porosity (vol \%) } & \multirow{2}{*}{$\begin{array}{c}\text { Bulk density } \\
\left(\mathrm{g} \cdot \mathrm{cm}^{-3}\right)\end{array}$} \\
\hline & & Total & Air-filled & \\
\hline Control $^{2}$ & 49.9 & 54,1 & 4.2 & 0.70 \\
\hline \multicolumn{5}{|l|}{ СТ (\%) } \\
\hline 22 & 45.8 & 51.5 & 5.3 & 0.76 \\
\hline 44 & 35.0 & 46.5 & 11.4 & 0.88 \\
\hline 66 & 21.0 & 39.1 & 18.0 & 0.89 \\
\hline \multicolumn{5}{|l|}{ FT $(\%)$} \\
\hline 22 & 51.4 & 55.0 & 3.6 & 0.68 \\
\hline 44 & 54,1 & 58.6 & 4.5 & 0.75 \\
\hline 66 & 52.3 & 59.1 & 6.8 & 0.69 \\
\hline L S $D_{0.05}$ & 3.8 & 3.9 & 1.8 & 0.04 \\
\hline
\end{tabular}

${ }^{2}$ Control medium formulated with 1 sand: 2 redwood sawdust (v/v).

Table 3. Growth characteristics for 'Bright Golden Anne' chrysanthemum grown in container media amended with coarse tire (CT) or fine tire (FT) material. Plants were harvested 10 weeks after planting. Values are means of five replicates.

\begin{tabular}{|c|c|c|c|c|c|c|}
\hline \multirow[b]{2}{*}{ Medium } & \multirow[b]{2}{*}{ Plant $\mathrm{ht}^{2}(\mathrm{~cm})$} & \multirow[b]{2}{*}{ Open } & \multirow[b]{2}{*}{ flowers/pot } & \multirow[b]{2}{*}{ Buds/pot } & \multicolumn{2}{|c|}{ Wt (g/pot) } \\
\hline & & & & & Fresh & Dry \\
\hline Control $^{y}$ & 28.8 & & 12.8 & 0 & 291 & 35.2 \\
\hline \multicolumn{7}{|l|}{ CT $(\%)$} \\
\hline 22 & 25.6 & & 11.6 & 0.4 & 227 & 28,7 \\
\hline 44 & 23.9 & & 11.8 & 0.2 & 169 & 21.0 \\
\hline 66 & 21,0 & & 10.4 & 1.6 & 97 & 13.5 \\
\hline \multicolumn{7}{|l|}{$\mathrm{FT}(\%)$} \\
\hline 22 & 24.5 & & 12.4 & 0 & 193 & 27.5 \\
\hline 44 & 23.3 & & 10.0 & 1.8 & 143 & 20.5 \\
\hline 66 & 23.9 & & 7.2 & 4.2 & 121 & 18.2 \\
\hline \multirow{2}{*}{\multicolumn{7}{|c|}{$\begin{array}{l}\mathrm{L} \& \mathrm{D}_{0.0 .5} \\
\text { Significance }\end{array}$}} \\
\hline & & & & & & \\
\hline \multicolumn{7}{|l|}{$\mathrm{CT}$} \\
\hline Linear & $* * *$ & & $*$ & NS & $* * *$ & $* * *$ \\
\hline Quadratic & NS & & NS & NS & NS & NS \\
\hline \multicolumn{7}{|l|}{ FT } \\
\hline Linear & $* * *$ & & $* * *$ & $* * *$ & $* * *$ & $* * *$ \\
\hline Quadratic & $* * *$ & & NS & $*$ & $* * *$ & $* * *$ \\
\hline
\end{tabular}

${ }^{2}$ Based on individual averages of four plants per pot.

'Control medium formulated with 1 sand $: 2$ redwood sawdust (v/v).

Ns,:**t Nonsignificant or significant at $P \leq 0.05$ or 0.001 , respectively. grown in medium amended with FT compared to CT. Despite the negative impacts of rubber amendment on growth, all plants were judged at harvest to be of marketable quality, based on the criteria for plant dimensions, floral display, and foliar quality outlined by Sachs et al. (1975).

Leaf tissue analysis revealed significant reductions in tissue $\mathrm{K}$ and $\mathrm{P}$ with $\mathrm{CT}$ and $\mathrm{FT}$ amendments (Table 4). Calcium and $\mathrm{Mg}$ concentrations were reduced by CT but not by FT, whereas $\mathrm{N}$ and $\mathrm{Cu}$ levels were reduced only by FT. Iron and Mn were not affected by the treatments (data not shown). Although the rubber amendments significantly affected several plant nutrients, most ion values were within the sufficient range for chrysanthemum production (Jones et al., 1991), with the exception of $\mathrm{Zn}$. Compared to controls, tissue $\mathrm{Zn}$ levels increased 12- and 74-fold in the 66\% CT and FT treatments, respectively. These values exceed by up to an order of magnitude the published sufficiency range for chrysanthemum Zn levels (20-250 mg. $\mathrm{kg}^{-1}$ ) (Jones et al., 1991) and are much higher than reported by Gogue and Sanderson (1975). Tissue Zn concentrations similar to those found in the CT treatments have been reported for chrysanthemum grown in media amended with organic waste materials (Williams and Nelson, 1992), fertilized with sewage sludge(Kirkham, 1977), or irrigated with nutrient solution amended with $0.1 \mathrm{~mm} \mathrm{Zn} \mathrm{(Patel} \mathrm{et} \mathrm{al.,} \mathrm{1976).} \mathrm{Chapman}$ (1966) indicated that tissue $\mathrm{Zn}>400 \mathrm{mg} \cdot \mathrm{kg}^{-1}$ is excessive for most plants, although Chang et al. (1992) reported that $\mathrm{Zn}$ levels causing 50\% growth reduction ranged from 375 in bush bean (Phaseolus vulgaris L.) to $2200 \mathrm{mg} \cdot \mathrm{kg}^{-1}$ in corn (Zea mays L.). In our study, analysis of data by multiple linear regression indicated that tissue $\mathrm{Zn}$ accounted for $89 \%$ and $85 \%$ of the variability in plant dry weight for the CT and FT treatments, respectively. Adding tissue $\mathrm{Ca}$ as a variable increased the $R^{2}$ to $94 \%$ for the CT treatments, but adding tissue $\mathrm{Mg}$ as a variable increased the $R^{2}$ to $91 \%$ for the FT treatments. The accumulation of $\mathrm{Zn}$ in leaf tissue is likely due to use of $\mathrm{Zn}$-containing compounds (zinc dimethyl- and zinc diethyldithiocarbamate) as vulcanizing accelerators in tire manufacturing (Yamaguchi et al., 199 1) Other than these growth reductions, there were no apparent toxicity symptoms in any of the plants at harvest. There was also no indication of heavy metal $(\mathrm{Cd}, \mathrm{Cr}, \mathrm{Ni}$, and $\mathrm{Pb})$ or $\mathrm{Na}$ accumulation by plants in any of the treatments, with most values near or below the limits of detection (data not shown).

The dry weight data suggest that some factor other than $\mathrm{Zn}$ was inhibiting growth of plants in the CT treatments. Tissue $\mathrm{Zn}$ increased to $522 \mathrm{mg} \cdot \mathrm{kg}^{-1}$ in the $66 \%$ CT treatment, with an associated reduction in dry weight of $67 \%$. This result contrasts with that for $22 \% \mathrm{FT}$, which had nearly three times greater tissue $\mathrm{Zn}$ concentration but only a $34 \%$ growth reduction. Although plants were watered daily, reduced growth with 66\% CT could have been due to water stress, because the container capacity of this medium was only $21 \%$. 
Table 4. Mineral ion concentrations of 'Bright Golden Anne' chrysanthemum grown in container media amended with coarse tire (CT) or tine tire (FT) material. Values are means of five replicates.

\begin{tabular}{|c|c|c|c|c|c|c|c|}
\hline \multirow[b]{2}{*}{ Medium } & \multicolumn{5}{|c|}{ Ion conen (\%) } & \multicolumn{2}{|c|}{ Ion concn (mg.kg-1) } \\
\hline & $\mathbf{N}$ & $\mathrm{P}$ & $\bar{K}$ & $\mathbf{C a}$ & $\overline{\mathrm{Mg}}$ & $\mathrm{Zn}$ & $\overline{\mathrm{Cu}}$ \\
\hline Control $^{\mathrm{z}}$ & 4.72 & 0.36 & 4.05 & 2.08 & 0.79 & 42 & 11 \\
\hline CT (\%) & & & & & & & \\
\hline 22 & 4.84 & 0.39 & 4.08 & 1.86 & 0.63 & 162 & 12 \\
\hline 44 & 4.84 & 0.36 & 4.30 & 1.69 & 0.54 & 302 & 15 \\
\hline 66 & 4.93 & 0.30 & 3.87 & 1.64 & 0.55 & 522 & 8.8 \\
\hline \multicolumn{8}{|l|}{$\mathrm{FT}(\%)$} \\
\hline 22 & 4.64 & 0.30 & 4.15 & 2.03 & 0.85 & 1580 & 10 \\
\hline 44 & 4.37 & 0.30 & 3.97 & 2.00 & 1.05 & 2860 & 9.4 \\
\hline 66 & 4.18 & 0.24 & 3.42 & 2.17 & 1.06 & 3110 & 5.2 \\
\hline $\mathrm{LSD}_{0.05}$ & 0.23 & 0.04 & 0.33 & 0.15 & 0.10 & 398 & 4.1 \\
\hline \multicolumn{8}{|l|}{ Significance ${ }^{y}$} \\
\hline \multicolumn{8}{|l|}{ CT } \\
\hline Linear & NS & $* *$ & NS & $* * *$ & $* * *$ & $*$ & NS \\
\hline Quadratic & NS & $* *$ & NS & NS & $*$ & NS & $*$ \\
\hline $\mathrm{FT}$ & & & & & & & \\
\hline Linear & $* * *$ & $* * *$ & $* * *$ & NS & $* * *$ & $* * *$ & $* *$ \\
\hline Quadratic & NS & NS & $*$ & $*$ & NS & $* * *$ & NS \\
\hline
\end{tabular}

${ }^{2}$ Control medium formulated with 1 sand : 2 redwood sawdust (v/v).

${ }^{* *}$ Nonsignificant or significant at $P \leq 0.05,0.01$, or 0.001 , respectively.

Our results suggest that ground automobile tires might be used as a component of container media, at least in chrysanthemum production. However, it is apparent from the severe growth reductions at the highest amendment rates that ground rubber cannot completely substitute for organic matter. Further, the accumulation of $\mathrm{Zn}$ to high tissue levels indicates that all but the most Zn-tolerant plants might suffer toxicity when grown in rubber-containing media, Based on the tissue data, ground rubber may have value as a source of $\mathrm{Zn}$ in field situations where $\mathrm{Zn}$ deficiency is a problem. agricultural land application of municipal sewage sludges. J. Environ. Qual. 21:521-536.

Chapman, H.D. 1966. Zinc, p. 484-499. In: H.D. Chapman (cd.). Diagnostic criteria for plants and soils. Univ. of California, Riverside.

Gogue, G.J. and K.C. Sanderson. 1975. Municipal compost as a medium amendment for chrysanthemum culture. J. Amer. Soc. Hort. Sci. 100:213-216.

Hoagland, D.R. and D.I. Amen. 1950. The water culture method for growing plants without soil. California Agr. Expt. Sta. Circ. 347.

Jones, J.B., Jr., B. Wolf, and H.A. Mills. 1991. Plant analysis handbook. Micro-Macro Publishing, Athens, Ga.

Kirkham, M.B. 1977. Elemental composition of sludge-fertilized chrysanthemums. J. Amer. Soc. Hort. Sci. 102:352-354.

Matkin, O.A. and P. A, Chandler. 1957. The U.C.type soil mixes, p. 68-85. In: K.F. Baker (cd.). The UC system for producing healthy containergrown plants. California Agr. Expt. Sta., Berkeley, Manual 23.

Milks, R.R., W.C. Fonteno, and R.A. Larson. 1989 Hydrology of horticultural substrates: III. Predicting air and water content of limited volume plug cells: J. Amer. Soc. Hort. Sci. 114:57-61.

Patel, P. M., A. Wallace, and R.T. Mueller. 1976. Some effects of copper, cobalt, cadmium, zinc, nickel, and chromium on growth and mineral element concentration in chrysanthemum. J. Amer. Soc. Hort. Sci. 101:553-556.

Sachs, R. M., A.M. Kofranek, and W.P. Hackett. 1975. Evaluating new pot plant species. Florists Rev. 159:35-36, 80-84.

Williams, K.A. and P.V. Nelson. 1992. Low, controlled nutrient availability provided by organic waste materials for chrysanthemum. J. Amer. Soc. Hort. Sci. 117:422-429.

Yamaguchi, T., A. Yamauchi, H. Yamazaki, and Y. Kakiuchi. 1991. Mutagenicity of rubber additives in tire (in Japanese with English summary). Eisei Kagaku 37:6-13. 